Role of agricultural engineering in environmental and sustainable development for the valley and delta areas. 1688 - 1709

\title{
DEVELOPMENT OF A LOCAL SINGLE SCREW EXTRUDER FOR PRODUCING EXPNDED BREAKFAST CREAL
}

\author{
Kaddour.O.A 1
}

\begin{abstract}
Extrusion cooking has been used in industries for many years to produce various types of human foods and animal feeds. Twin screw extrusion used for the production of expanded breakfast cereal. This work aimed to develop a local single screw extruder to produce the breakfast cereal by modifying extruder die and cutter knife units. The performance of the developed extruder was studied as a function of change in the physical and mechanical factors affecting the shear in extrusion barrel such as screw speed of (354and 438 RPM), the clearance between the last screw unit and die of (3,10 and 20mm), number of holes in the die (1,3,6 and 9 holes) as mechanical factors and formula moisture content of (19,24 and 29\%w.b.) as physical factors. Results indicated that the most effective operating range for these parameters was $438 \mathrm{rpm}, 3 \mathrm{~mm}, 6$ holes and $24 \%$ w.b., respectively, which led to an extruder productivity of 253.56 $\mathrm{kg} / \mathrm{h}$, specific mechanical energy (SME) of $67 \mathrm{~kW} . \mathrm{h} / \mathrm{ton}$ and good product quality with $0.716 \mathrm{~g} / \mathrm{cm} 3$ product bulk density, $93.18 \%$ durability, 1.63 expansion ratio and $41.83 \%$ cereal water absorption.
\end{abstract}

\section{FINTRODUCTION}

$\mathrm{F}$ lood extrusion has been practiced for well over a century. The first major commercial application of the screw extruder to food processing was the production of pasta. This low shear, low temperature forming process found first commercial production in the 1920s and 1930s and remains a standard production process into the twenty-first century. The screw extruder was first used as a continuous cooking device in the late-'30s. Today, the extrusion cooker has become the primary continuous cooking apparatus in the commercial production of many snacks, cereals, aquatic feeds, and pet foods.

\footnotetext{
${ }^{1}$ Senior researcher- Agriculture Engineering Research Institute (AEnRI).
} 
Extrusion processing used in the cereal breakfast industry was designed as a short time, high temperature and high pressure cooking method (Rooney and Serna-Saldivar 1987). Corn meal and flour are transformed into a variety of products with multiple sizes and shapes (Alexander 1987).

Alexander (1987) mentioned that besides equipment design, processing variables such as moisture, temperature, screw speeds and die configuration impacted extruded cereal properties including: degree of cooking, density, viscosity and water absorption. There are many characteristics of corn meal based extrudates. Sectional expansion index (SEI), as described by Alvarez-Martinez et al (1988), was designed for extruded products and used as a tool of analysis; then found a mathematical model showed SEI, volume expansion index (VEI) and longitudinal expansion index (LEI) were affected by cooking temperature. Positive increments of SEI, due to feeding big grit particles, were related negatively to bulk density (Bhattacharya and Hanna 1987).

Colonna et al (1989) reported that another property directly affected by expansion was bulk density and was related directly to LEI and inversely related to SEI

Hseih et al (1990) showed addition of ingredients such as sugar, soy flour and salt to corn meal resulted in higher bulk density of extrudates. In the same experiments, color differences were found when using added ingredients.

Hoseney (1994) described the extrusion process as a tool for processing cereal flour and materials of low moisture content. He found increased feed particle size and feed moisture content reduced longitudinal expansion and resulted in lower extrudate density

Processing variables also affected expansion characteristics. Several investigators found a direct relationship between expansion index and cooking temperature and/or screw speed (Desrumaux 1998).

Patil et al (2000) said that, food extruders are generally available with segmented screws and barrel section, which facilitates total control 
over the configuration of the machine to get a variety of process parameters combinations. Extrusion cooking is also a high-pressure operation that provides sudden expansion of the processed product when it comes out of die opening and provides porous and crunchy texture. Expansion takes place due to sudden exit of molten mass from the restricted die from very high pressure to atmosphere giving improved texture to the extrudate. The expansion of extrudates varies from 2 to 25 times depending on the type of extruder and the particular raw material and ingredients used for extrusion. In case of forming extruders, where high moisture material was only partially cooked and later dried, expansion was generally low as the extrudate in different shapes was later on subjected to deep fat frying before serving. However, with products like corn curls, which are directly consumed after coating with salt and cheese, a higher expansion is desirable.

Extrusion cooking is a versatile and a very important process in the food industry. It is used in the production of variety of snacks and breakfast cereals-type products, confectionery items, texturized vegetable proteins and pet foods. The extrudate quality is dependant on the machine as well as material parameters .Many researchers have reported empirical correlations between the machine parameters screw speed, temperature of the barrel and the material parameters moisture content, proximate composition of the mix and particle size, with product characteristics (Ding et al., 2005).

System variables such as specific mechanical energy (SME), pressure before the die $(\mathrm{P})$ and net torque $(\mathrm{T})$ are important system variables in extrusion cooking. These parameters reflect the combined effect of machine parameters (screw speed, L/D ratio, compression ratio, screw configuration, temperature profile along the length of the barrel section and feed rate) and feed properties (;food micronutrients; particle size and moisture content of the feed) on system performance which are often used as parameters for scale-up operations to large capacity commercial applications. (Patil et al 2005).

Nehrow et al( 2006) said that, Ingredient blends containing 28\% protein with distillers dried grains with solubles, soy flour, corn flour, fish meal, 
mineral mix and vitamin mix was extruded in a C.W. Brabender single screw laboratory extruder using 7 different die nozzles. The die nozzle diameter (D), length (L) and L/D ratio of the dies were in the range of $2.0 \mathrm{~mm}$ to $6.0 \mathrm{~mm}, 10.0 \mathrm{~mm}$ to $30.0 \mathrm{~mm}$ and 3.33 to 10.00 , respectively. The moisture content of the ingredient mix was varied from $15 \%$ to $25 \%$ and the temperature of the transition zone and die section were varied from $100^{\circ} \mathrm{C}$ to $140^{\circ} \mathrm{C}$. The response variables studied was found to be over 0.6. Increasing the moisture content of the ingredient mix from $15 \%$ to $25 \%$ had resulted in $2.0 \%, 16.0 \%, 13.2 \%, 3.2 \%, 63.7 \%$ decrease in bulk density, water solubility index, sinking velocity, mass flow rate and absolute pressure respectively and $11.6 \%, 16.2 \%$ increase in pellet durability and water absorption index respectively. Increasing the cooking temperature had resulted in $17.0 \%, 5.9 \%, 35.4 \%, 50.6 \%, 28.8 \%$, $33.9 \%, 33.9 \%$ decrease in unit density, pellet durability, sinking velocity, absolute pressure, specific mechanical energy, torque and apparent viscosity of the dough respectively, and 23.6 to $49.1 \%$ and $16.9 \%$ increase in dough temperature and water absorption index, respectively.

The objectives of this manuscript are to develop and test a local single screw extruder by modifying the die, die holder and cutter knife and study the physical and mechanical factors affecting high quality of produced breakfast cereal.

\section{MATERIAL AND METHODS}

\section{Materials:}

\section{1-Composition of the breakfast cereal formula:}

A breakfast cereal experimental formula was used in the present study, the composition of the formula were wheat flour $72.4 \%$, rice flour $25.1 \%$, emulsifier $0.5 \%$, baking soda $0.5 \%$, and salt $1.5 \%$. The particle size of the formula was $1 \mathrm{~mm}$ or less. The milling sugar added by $5 \%$ to the cereal as coating substance in durability box.

\section{2- Local single screw extruder}

Local single screw extruder with medium shear screw profile (single flight -single flight- -single flight- double flight -double flight). The constant conditions of breakfast cereal raw material, and the extruder were1- For raw material: moisture $12.3 \%$, bulk density of $633.2 \mathrm{~kg} \mathrm{~cm}^{3}$ 
of $1 \mathrm{~mm}$ or less formula particle size.2-For the extruder: feed temperature of $22 \mathrm{C}^{\circ}$, feed rate of $260 \mathrm{kglh}$ and feed screw speed of $85 \mathrm{rpm}$ and extruder cutter knife speed of 2373rpm.

\section{The specification of the single screw extruder:}

\section{A- Extruder feeder:}

Feeding unit is made from iron sheet metal (2 mm thick.), with dimensions of $(36 \times 28 \times 62 \mathrm{~cm})$. The capacity of the hopper is around 30 $\mathrm{kg}$ with feeding hole of $10 \mathrm{~cm}$. at the end of the hopper. Feeding auger shaft is supported in the bottom of the feeding hopper by two flange bearings, to transmit the formula from the feeding unit to the extrusion unit. It was constructed from $3 \mathrm{~mm}$ iron steel sheet with $50 \mathrm{~mm}$ outer diameter, and assembled on $20 \mathrm{~mm}$ shaft with $35 \mathrm{~mm}$ pitch, and operated by an electrical variable speed motor using two gears, motor gear with 18 teeth, and screw shaft gear with 50 teeth. The feeding auger speed could be controlled by a key to increase or decrease the speed. A mixer working in the middle of feeding hopper used to mix and move the additional materials. Mixer shaft has dimensions of $22 \mathrm{~mm}$ diameter and $360 \mathrm{~mm}$ length with eight blades supported on the shaft to re-mix the formula over the feeding auger. The mixer shaft takes the power from the feeding auger shaft by gears 1:1 Fig(1).
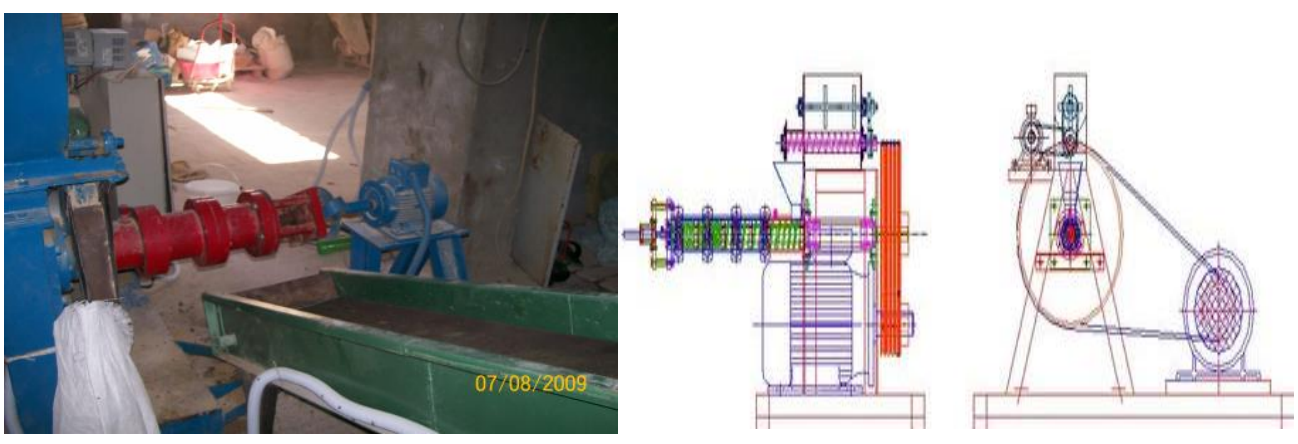

Fig.(1): local single screw extruder

\section{B-Extruder screws and barrel}

A compressing shaft made from hard steel 52, with dimensions of 145.5 $\mathrm{cm}$ long and $50 \mathrm{~mm}$ diameter and keyway $12 \times 6 \mathrm{~mm}$ is used to support the screws and the steam-lock to prevent slipping of the screws. On the 
other hand an operating pulley with $64 \mathrm{~cm}$ diameter and $5 \mathrm{~V}$ belts is connected to the opposite side of the main shaft to transmit the power form the main motor to the main shaft, while the shaft supported on two tapered bearings inside oil housing.

The compressing screw consists of five units, each unit has demission of $150 \mathrm{~mm}$ long, $95 \mathrm{~mm}$ diameter, with pitch $35 \mathrm{~mm}$ for the single flight screw and $17.5 \mathrm{~mm}$ pitch for the double flight screw, with a key way 12 x $6 \mathrm{~mm}$. At the front of the screw there is long hole to allow the end bolt to hold all the units with the main compressing shaft as illustrated in Fig(2).

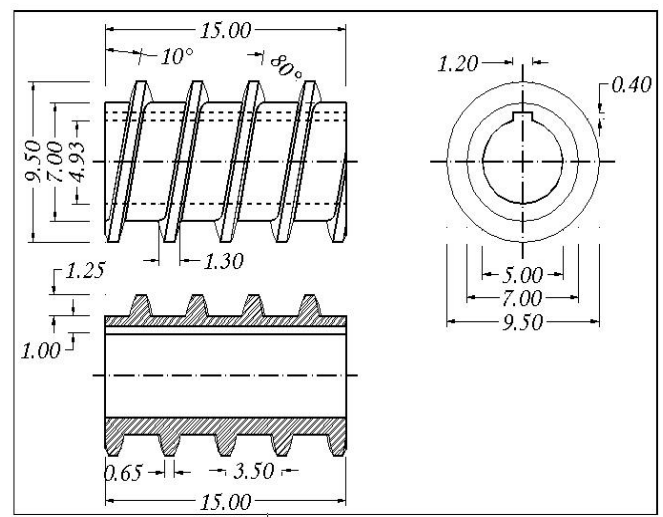

a- Single flight screw

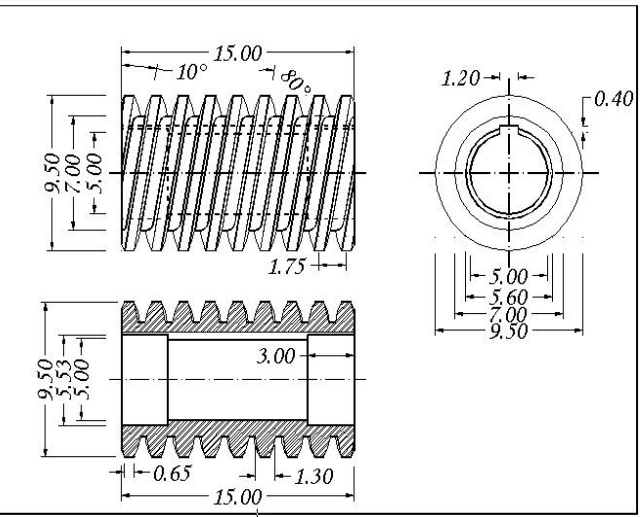

b- Double flight screw

Fig.(2):The single and double flight screw.

The extruder barrel covering the compressing screw units consists of four parts made of hard steel. The first part is the feeding cylinder fixed with the base under the feeding unit by six screw bolts (M12x1.5). Its dimensions (250 $\mathrm{mm}$ long , $104 \mathrm{~mm}$ diameter and $12 \mathrm{~mm}$ thick), It has a square hole of $57 \times 57 \mathrm{~mm}$ under the feeding unit, while the internal surface has incisions to let the meal pass forward with the direction of screw rotation. The dimensions of the next three parts were $(180 \mathrm{~mm}$ long, $104 \mathrm{~mm}$ internal diameter, and $12 \mathrm{~mm}$ thick). They have the same internal incisions as shown in Fig. (3)

\section{C-Extruder die holder and cutter knives}

The old die which blocked the cylinder from the end was fixed in the die head using screw bolt (M8x1.2) and two guides to prevent the rotation with operation and keep the clearance with the screw shaft at $3 \mathrm{~mm}$. 


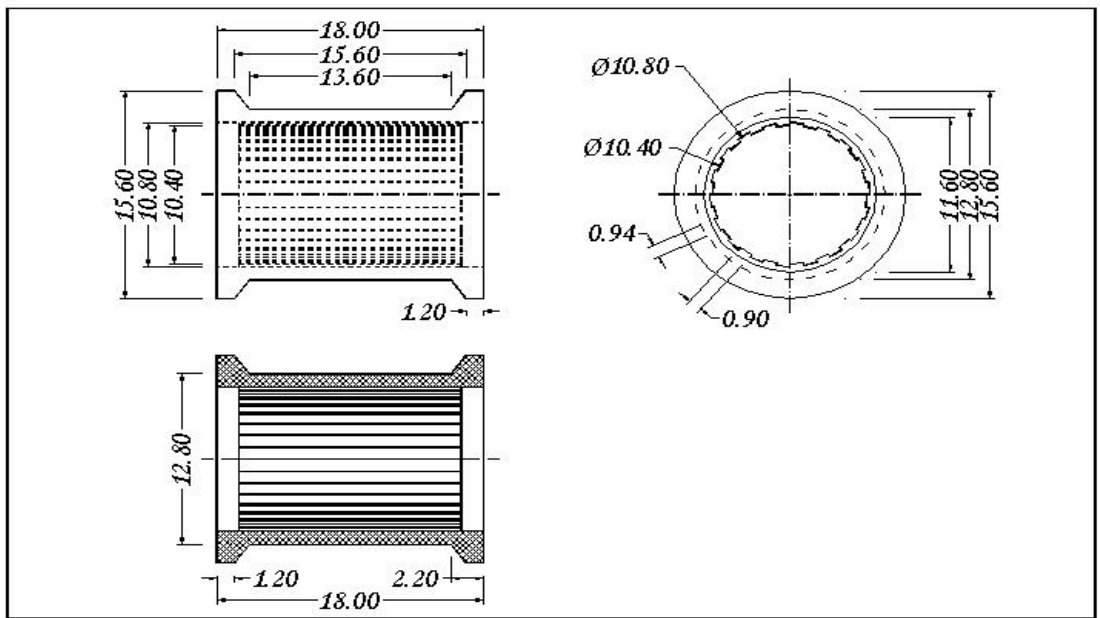

Fig.(3): Schematic diagram of the extruder cylinders

It was made from hard steel (104 and $94 \mathrm{~mm}$ for the two levels of the outside diameters, $25 \mathrm{~mm}$ thick).The developed die is a copy of new american extruder die design. The die holder has diameter of $104 \mathrm{~mm}$, and $13 \mathrm{~mm}$ total thickness, the die set consists of 5 unit, each unit has dimension of $13 \mathrm{~mm}$ thickness , $5 \mathrm{~mm}$ die hole diameter, die hole land length of $7 \mathrm{~mm}$, die hole entry diameter of $7.5 \mathrm{~mm}$. This design allow for the controlling the die out put area and change the product diameter and shape easily. The old cutter knife was made from steel 37 (100, and 25 $\mathrm{mm}$ for the outer and Inner diameters with $10 \mathrm{~mm}$ thick)and consists of 4 blades with a sharp edges. The developed cutter knives has new design with spring to set the knife blades on the die holder through the running vibration , this design used to control the product length by controlling the number of blades and the rotating speed using an electrical digital inverter as shown in Fig. (4)

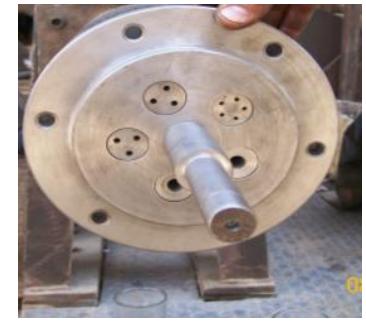

The developed die holder

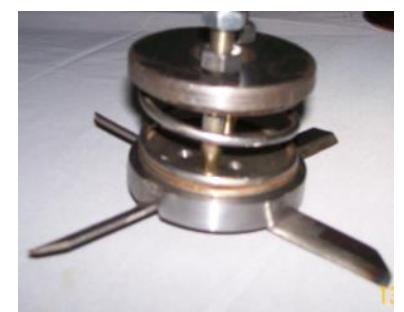

The developed cutter knife

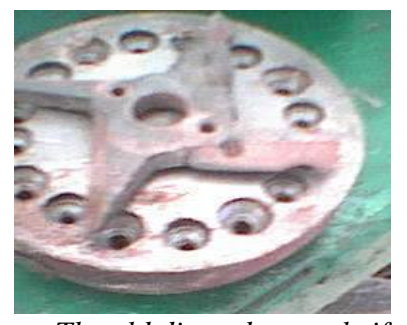

The old die and cutter knife

Fig.(4):Extruder die holder and cutter knives before and after development 


\section{D-Extruder Power transmission and electric control}

The main electric motor has output power of $50 \mathrm{hp}, 43 \mathrm{~A}$.Feeder variable mechanical speed motor by output power of the $2 \mathrm{hp}$, and $18 \mathrm{~A}$ has speed limits from 96 to $480 \mathrm{rpm}$. Cutter knives motor $2 \mathrm{hp}$, and $18 \mathrm{~A}$ $2980 \mathrm{rpm}$. Motor load Amber and voltage scales, push bottom motors on /of and over load safety switches

\section{3- Measuring devices:.}

* Weighing scale, other scale used for bulk density and durability measurements

*local durability turning box 3 cells, Rotating speed of rpm. Fig. (5)

*Stop watch Casio FX53

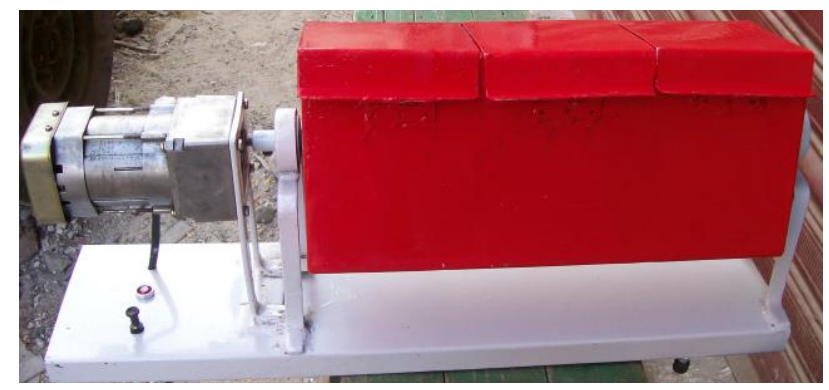

Fig.(5): Local manufactured durability box

\section{Methods:}

\section{Processing Parameters:}

Breakfast cereal formula was extruded by local single screw extruder system to study the physical and mechanical factors affecting the extruder efficiency and product quality Two different extruder screw speeds of 354 and $438 \mathrm{rpm}$ (extruder speed limit 300-450 rpm), three clearances between the last screw unit and die of $(3,10$ and $20 \mathrm{~mm})$, four numbers of holes in the die holding (1,3,6 and 9 holes)were examined as a mechanical parameters and three levels of formula moisture content of 19, 24 and 29\% (extruder moisture limit 18-35\%) were examined as physical parameters.

\section{Evaluation of extruder efficiency and product quality Performance}

Breakfast cereal were produced on a local single screw extruder using dies with $5 \mathrm{~mm}$ diameter circular openings. The extruder factors 
performance was evaluated for extruder efficiency and pellets quality based on the following measurements:

1- Extruder production rate was measured for each treatment by taking sample for $2 \mathrm{~min}$ after $10 \mathrm{~min}$. of extruder running at steady condition

2- Specific mechanical energy (SME), was calculated as the following relation:

$$
\text { Total consumed power, }(k W)=\frac{\sqrt{3} I V \eta \cos \theta}{1000}
$$

Where: $\mathrm{I}=$ Line current strength in amperes.

$\mathrm{V}=$ Potential difference (Voltage) being equal to $380 \mathrm{~V}$.

$\operatorname{Cos} \theta=$ Power factor (being equal to 0.84 ).

$\eta \quad=$ Mechanical efficiency assumed $(90 \%)$.

The energy requirement in $(\mathrm{kW} . \mathrm{h} / \mathrm{ton})$ was calculated by the following equation:

$$
\text { Energyconsumed }=\frac{P}{Q}=k W . h / \text { ton }
$$

Where: $\mathrm{P}=$ The consumed power for mixing ration, $\mathrm{kW}$.

$\mathrm{Q}=$ Machinery line productivity, ton $/ \mathrm{h}$.

3- Pellet bulk density was calculated for irregular products by the standard methods of ASTM (B 873-96 and D 4914-89)

$$
\text { Bulk Density }\left(\mathrm{g} / \mathrm{cm}^{3}\right)=\frac{W d}{V d}
$$

Where: Wd: pellets sample mass (g), Vd: pellets sample volume $\left(\mathrm{cm}^{3}\right)$ 4- product durability was determined as per ASAE standards method S269.4 DEC01(2000), at 3 replicates ( mass of each one was $500 \mathrm{~g}$ ) using turning box for $10 \mathrm{~min}$.

$$
\operatorname{Durability}(\%)=\frac{W a}{W b} x 100
$$

Where: Wa :pellets mass after treatment ( $\mathrm{g}$ ),

$\mathrm{Wb}$ : pellets mass before treatment $(\mathrm{g})$

5- Product diameter was determined by digital scale

6- Product expansion ratio was determined by AACC 44-15 method (AACC, 1984).

$$
S E I=\frac{D_{e}^{2}}{D_{d}^{2}}(\text { ratio })
$$


Where SEI=Expansion ratio, $\mathrm{D}_{\mathrm{e}}=$ Diameter of the extruded rod, $\mathrm{mm}$ and $\mathrm{D}_{\mathrm{d}}=$ diameter of the die opening, $\mathrm{mm}$.

7- Cereal water absorption was determined by the method followed by (Jones et al. 2000.)

A- Samples were collected from dried product, weigh 10 grams of product(w1) $\mathrm{g}$

B- Individual samples were placed in a bowl and added $100 \mathrm{ml} \mathrm{milk}$ and begin timing

C- After 3 minutes whole sample were removed simultaneously

D- Immediately the sample was placed on dry paper towel and gently all surface moisture was removed

E- The sample was reweigh (w2) g and this value from was subtract from original weight(w2-w1) $g$

$$
\text { Water absorption } \%=\frac{w 2-w 1}{w 1} X 100
$$

\section{RESULTS AND DISCUSSION}

Evaluation of Extruder performance and product quality was carried out under the following items:.

\section{1- Extruder Productivity}

Extrusion screw speed, number of holes in the die, clearance between the last screw and extrusion die and formula moisture content are the most factors affecting the extruder production rate. Data in Fig (6) indicated that increasing the extrusion screw speed from 354, to $438 \mathrm{rpm}$ decreased the extruder productivity from $151.71,148.9$ and 141.63 to $93.18,92.34$ and $90.15 \mathrm{~kg} / \mathrm{h}$ at formula moisture content of $19 \%$, using number of holes of 1 hole, from $191.6,188.79$ and 181.52 to $182.87,180.06$ and $172.79 \mathrm{~kg} / \mathrm{h}$ at formula moisture content of $19 \%$ ' using number of holes of 3hole, at clearance between the last screw unit and die of 3, 10 and 20 $\mathrm{mm}$ respectively. Meanwhile data in the same figure showed that increasing the screw speed from 354 to $438 \mathrm{rpm}$ increased the extrusion productivity from $229.48,226.67$ and 219.4 to $249,246.19$ and 238.92 $\mathrm{kg} / \mathrm{h}$ at formula moisture content of $19 \%$ using number of holes of 9 holes, at clearance between the last screw unit and die of 3,10 and 20 $\mathrm{mm}$ respectively. 
The decrease in extruder productivity by increasing the extrusion screw speed from 354 to $438 \mathrm{rpm}$ using number of holes of 1 and 3 holes could be due to the increase in the specific mechanical energy (SME) inside the extrusion barrel and formula temperature using low output area, that lead to decrease the product mass by gelatinization of starch On another hand the productivity increased by increasing the screw speed using numbers of holes of 6 and 9 holes that could be due to decrease the shear inside extruder barrel and increased the product mass in the time unit. Also, the decrease in extruder productivity by increasing the clearance between the last screw and extruder die could be due to the increase in formula retention time inside the extrusion barrel that lead to decrease the product output in time unit.
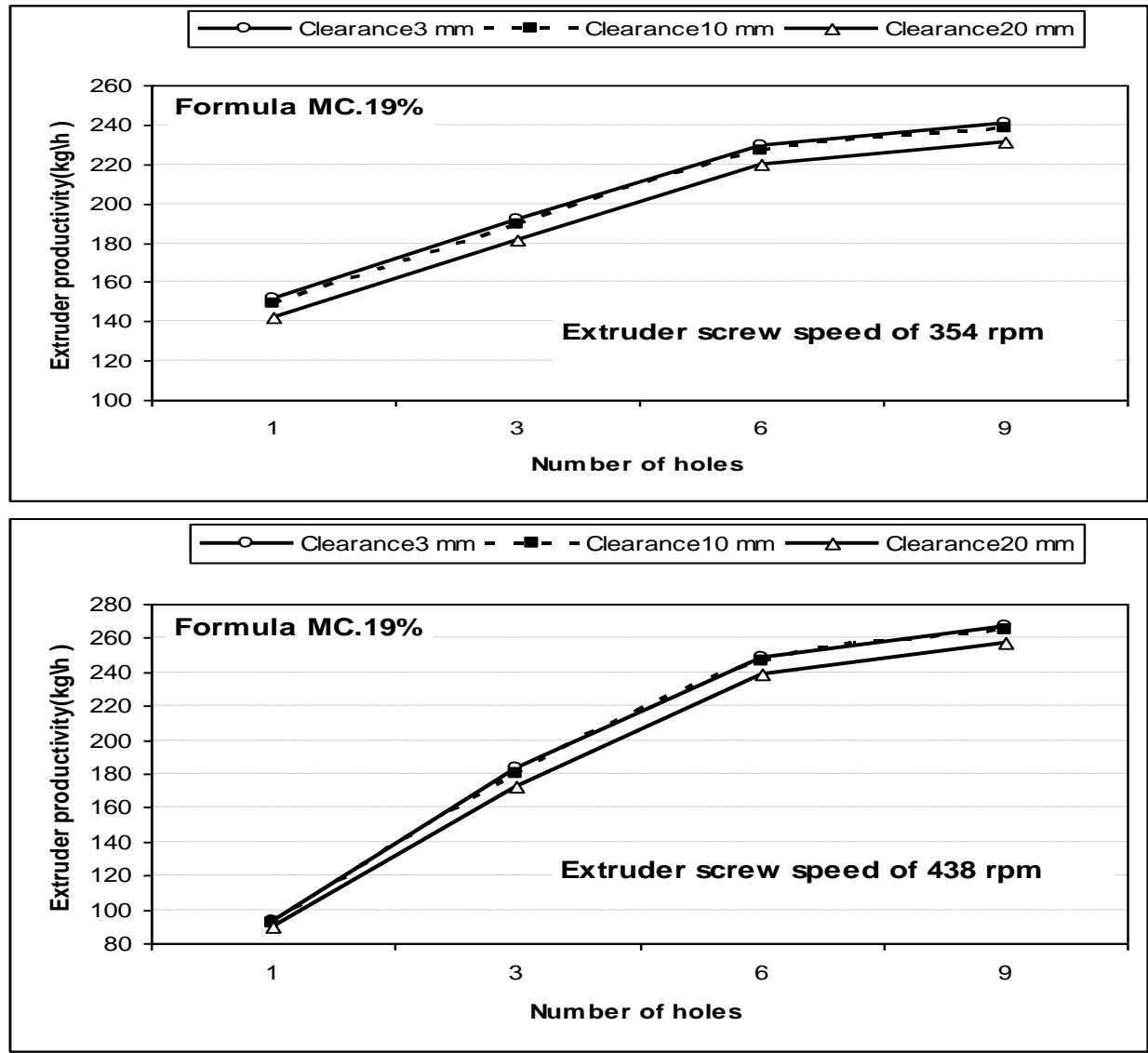

Fig.(6): Effect of physical and mechanical parameters on extruder productivity 


\section{2-Specific mechanical energy (SME)}

Reducing the consumed energy one of the goals of any industry, some industrial products required high levels of energy for product quality like expanded products and breakfast cereals. Fig(7) showed the effect of the different mechanical and physical factors on extrusion SME, Extrusion screw speed ,die number of holes, clearance between the last screw and extrusion die and formula moisture content are the most factors affecting the extruder production rate. Data indicated that increasing the extrusion screw speed from 354, to $438 \mathrm{rpm}$ increased the extruder SME from $118.53,123.68$ and 132.24 to $223.11,228.01$ and $231.80 \mathrm{~kW} . \mathrm{h} / \mathrm{ton}$
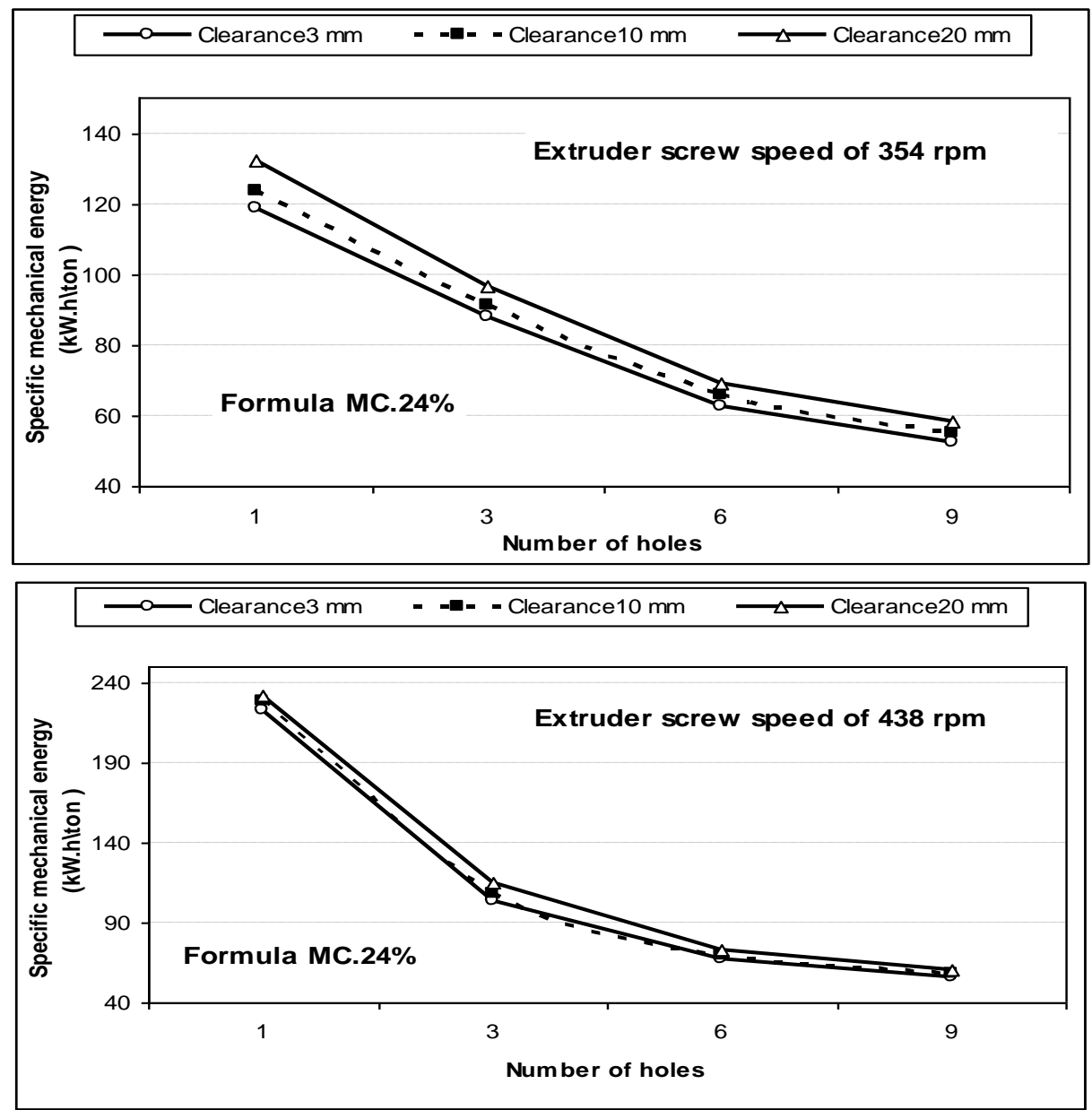

Fig.(7): Effect of physical and mechanical parameters on extruder specific mechanical energy. 
at formula moisture content of $24 \%$ using number of holes of 1 hole, from $87.76,91.40$ and 96.87 to $103.94,108.00$ and $114.42 \mathrm{~kW} . \mathrm{h} / \mathrm{ton}$ at formula moisture content of $24 \%$ using number of holes of 3 holes, from $62.90,65.64$ and 69.34 to $66.99,69.57$ and $73.09 \mathrm{~kW} . \mathrm{h} /$ ton at formula moisture content of $24 \%$ using number of holes of 6holes and from $52.39,54.88$ and 58.07 to $55.67,57.95$ and $60.91 \mathrm{~kW} . \mathrm{h} / \mathrm{ton}$ at formula moisture content of $24 \%$ using number of holes of 9holes, at clearance between the last screw unit and die of 3,10 and $20 \mathrm{~mm}$ respectively. The increase in SME by increasing the extruder screw speed from 354 to 438 rpm, increase the clearance between the last screw from 3 to 10 and 20 $\mathrm{mm}$ and decrease the die holes number from 1 to 3,6 and 9 holes could be due to the increase in motor load and power consumed with decrease in extruder productivity .

\section{3-Breakfast cereal bulk density.}

Bulk density one of the important measurements of any extruded product. Data showed in Fig (8) indicated that increasing the die hole numbers from 1 to 9 holes increased the product bulk density from 0.494 to $0.767,0.716$ and $0.658 \mathrm{~g} \mathrm{~cm}^{3}$, using formula moisture content of $19 \%$, from 0.526 to $0.799,0.748$ and $0.690 \mathrm{glcm}^{3}$, using formula moisture content of $24 \%$, from 0.571 to $0.844,0.793$ and $0.735 \mathrm{glcm}^{3}$, using formula moisture content of $29 \%$, using extruder screw speed of 438rpm , at clearance between the last screw unit and die of 3, 10 and $20 \mathrm{~mm}$ respectively. The increase in cereal bulk density by increasing die holes numbers from 1 to 9 and by increasing the formula moisture content from 19 t0 29\% could be due to the decrease in SME inside the extruder barrel and the decrease in cooking temperature by the increase in output opening area and formula moisture content, that lead to decrease the formula expansion (decrease in pellets air cells), pellets diameter and product volume. On another hand the decrease in product buck density by increasing the clearance between the extruder screw and die holder from 3 to $20 \mathrm{~mm}$, could be due to the increase in die house volume, the increase in formula retention time inside the extruder barrel, that lead to increase in formula temperature and cooking degree with increase in the air cells between the pellets granules and increase in pellets volume and decrease in pellets mass. 

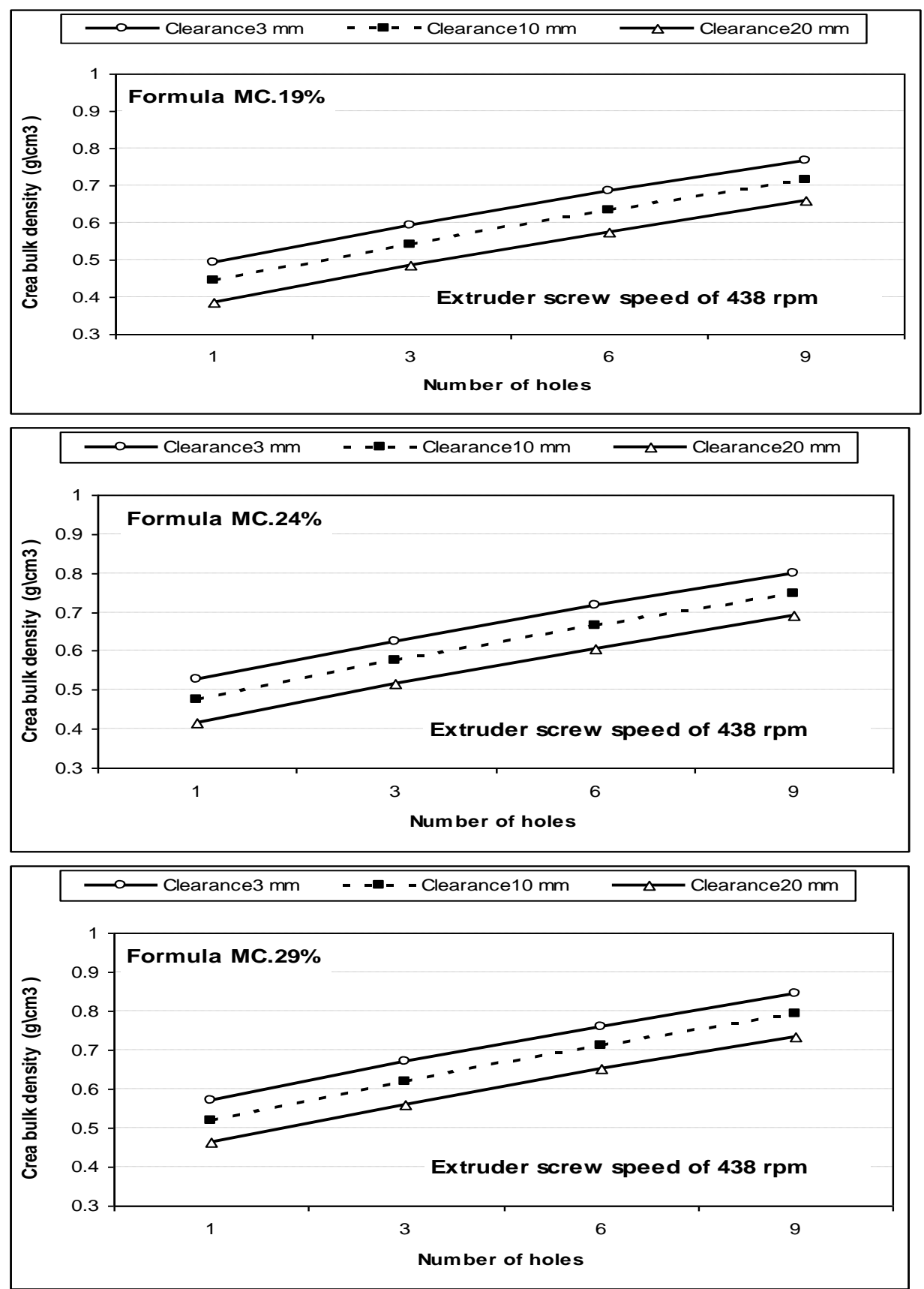

Fig.(8): Effect of physical and mechanical parameters on breakfast cereal bulk density

The $17^{\text {th }}$. Annual Conference of the Misr Society of Ag. Eng., 28 October, $2010 \quad-1701-$ 


\section{4-Breakfast cereal durability}

Durability of expanded products is a simulation measurement for product transportation and handling. Data in Fig. (9) indicated that, increasing the extrusion screw speed from 354, to $438 \mathrm{rpm}$ decreased the cereal durability, from $91.16,91.03$ and 90.54 to $89.2,89.07$ and $88.58 \%$ using number of holes of 1 hole, from 92.8, 92.67and 92.18 to 90.84, 90.71 and $90.22 \%$ using number of holes of 3holes, from 95.14, 95.01and 94.52 to 93.18, 93.05 and $92.56 \%$ using number of holes of 6holes and from $89.92,89.79$ and 89.3 to $87.96,87.83$ and $87.34 \%$ using number of holes
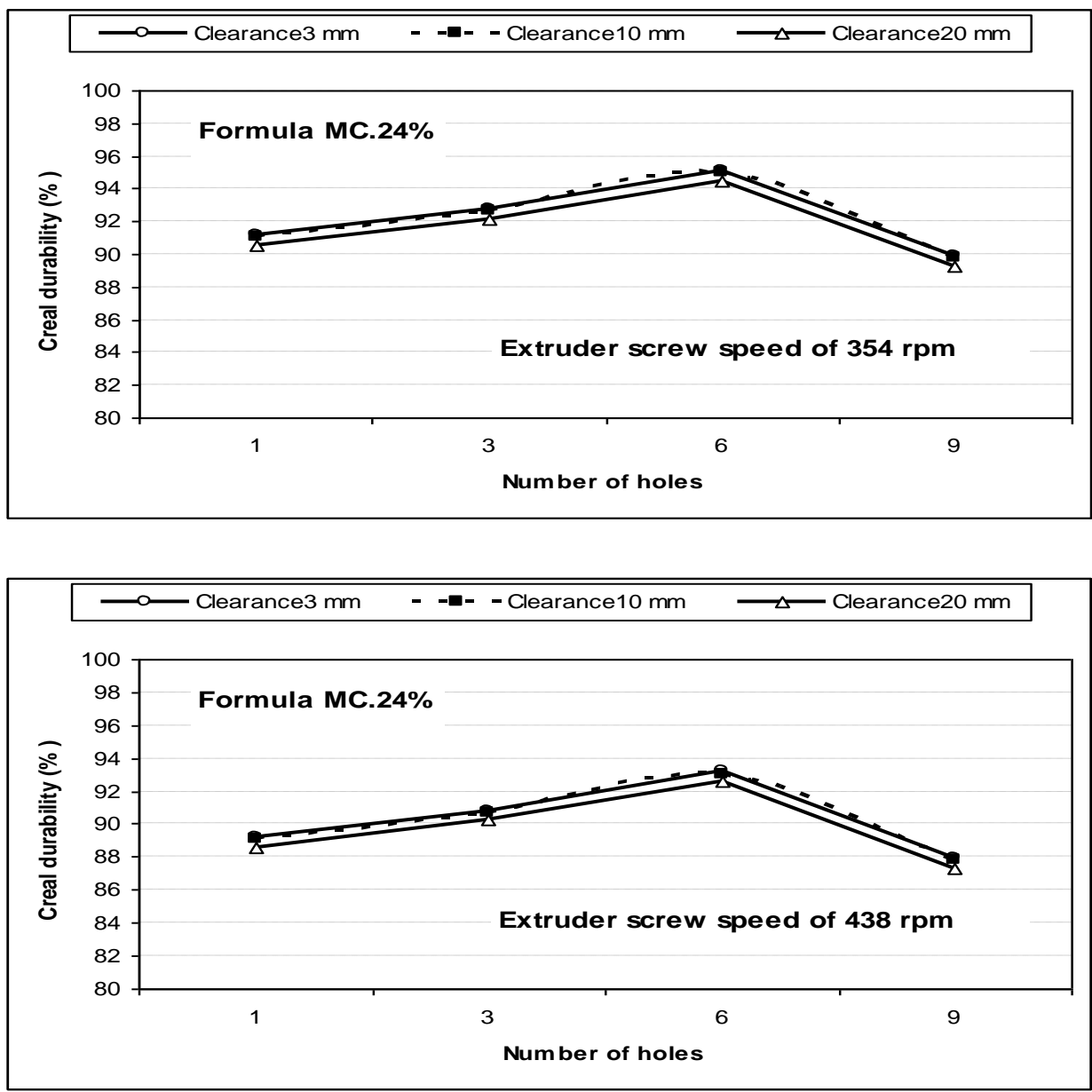

Fig. (9): Effect of physical and mechanical parameters on breakfastcereal durability. 
of 9holes, with formula moisture content of $24 \%$ at clearance between the extruder screw and die holder of 3,10 and $20 \mathrm{~mm}$ respectively. The decrease in product durability by increasing the screw speed from 354 to $438 \mathrm{rpm}$, and increase the clearance between the last screw and die from 3 to $20 \mathrm{~mm}$ could be due to the decrease in cereal compacting by increase the air cells area between pellets granules, that lead to increase the product breakage and increased the mash percentage after durability test measurement. While the increase of product durability by increasing the die hole number from 1 to 6 holes could be due to the decrease in cooking degree with decrease in air cells between the granules, but the decrease in product durability by increasing the number of holes to 9 holes could be due to the decrease in formula compacting by increased the die out put area.

\section{$\underline{\text { 5-Breakfast cereal expansion ratio }}$}

Data in Fig. (10) showed that, increasing the die holes number from 1 to 9 holes decreased the product expansion ratio from 1.97 to 1.07 using formula moisture content of $19 \%$, from 2.23 to 1.15 using formula moisture content of $24 \%$, from 2.56 to 1.39 using formula moisture content of $29 \%$, at clearance of $3 \mathrm{~mm}$, from 2.13 to 1.08 using formula moisture content of $19 \%$, from 2.40 to 1.28 using formula moisture content of $24 \%$, from 2.74 to 1.53 using formula moisture content of $29 \%$, at clearance of $10 \mathrm{~mm}$ and from 2.45 to 1.31 using formula moisture content of $19 \%$, from 2.75 to 1.52 using formula moisture content of $24 \%$, from 3.10 to 1.80 using formula moisture content of $29 \%$, at clearance of $20 \mathrm{~mm}$, using extruder screw speed of $438 \mathrm{rpm}$. The increase in cereal expansion ratio by decreasing the die hole number from 9 to 1 hole, increase the formula moisture content from 19 to $29 \%$, increase the clearance between the last screw and die from 3 to $20 \mathrm{~mm}$ ,could be due to the increase in cereal product diameter by increasing the SME inside the extrusion barrel and cooking degree with high increase in starch gelatinization ratio . 

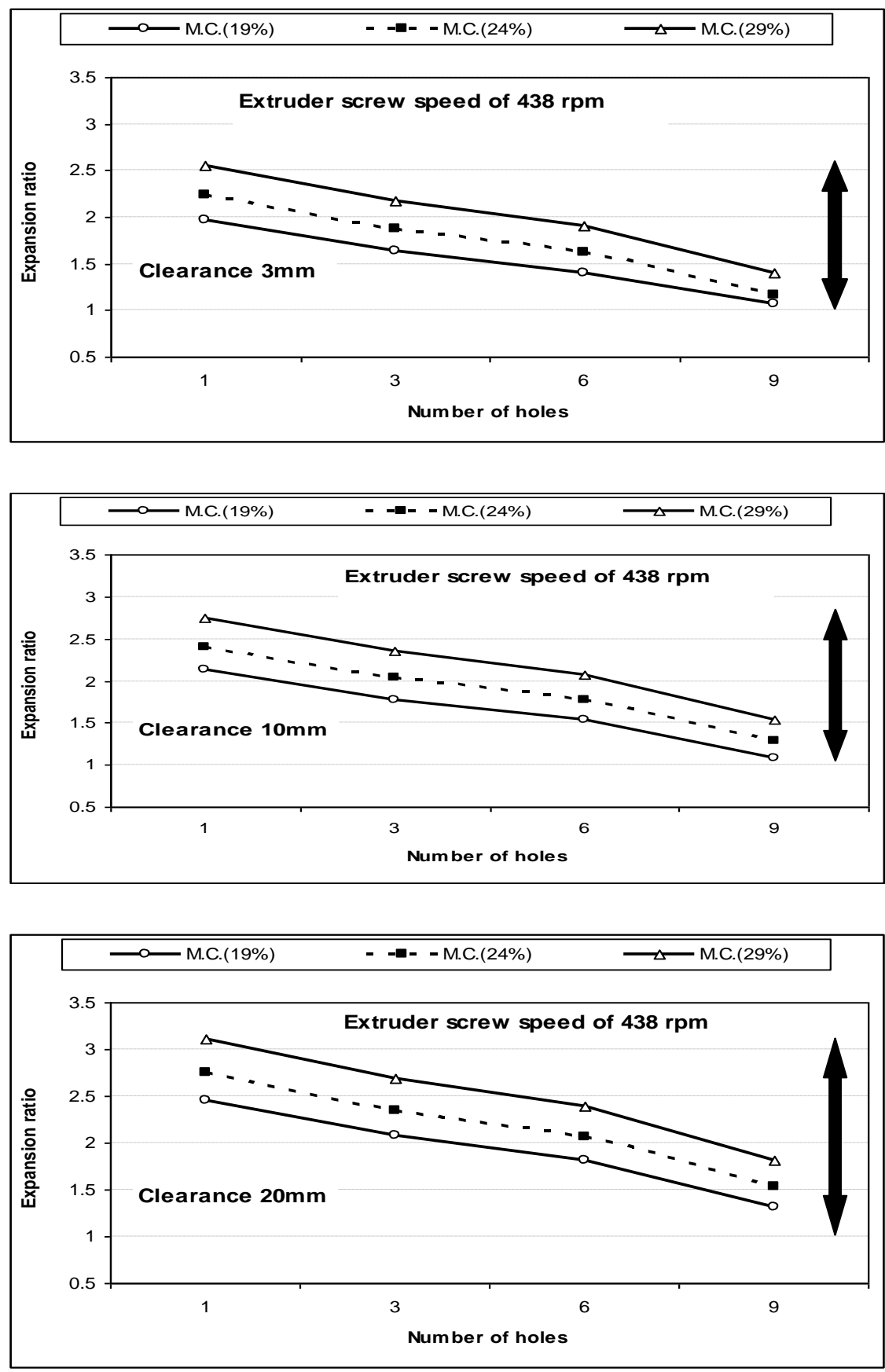

Fig. (10): Effect of physical and mechanical parameters on cereal expansion ratio 


\section{6-Breakfast cereal water absorption}

Water absorption of cereal products one of the most extruded food measurement. Data in Fig. (11) indicated that, increasing the die holes number from 1 to 9 holes increased the cereal water absorption from 23.66 to $49.24 \%$ using formula moisture content of $19 \%$, from 24.07 to $45.31 \%$ using formula moisture content of $24 \%$, from 20.28 to $46.52 \%$ using formula moisture content of $29 \%$, at clearance of $3 \mathrm{~mm}$, from 21.56 to $46.85 \%$ using formula moisture content of $19 \%$, from 20.63 to $45.83 \%$ using formula moisture content of $24 \%$, from 19.84 to $45.08 \%$ using formula moisture content of $29 \%$, at clearance of $10 \mathrm{~mm}$ and from 21.44 to $45.68 \%$ using formula moisture content of $19 \%$, from 17.51 to 44.00 using formula moisture content of $24 \%$, from 18.72 to 43.96 using formula moisture content of $29 \%$, at clearance of $20 \mathrm{~mm}$, using extruder screw speed of $438 \mathrm{rpm}$. The increase in cereal water absorption by increasing the die holes number from 1 to 9 holes, decrease the clearance between the last screw and die from 20 to $3 \mathrm{~mm}$, decrease the formula moisture content from 29 to $19 \%$, could be due to the decrease in SME inside the extrusion barrel that lead to decrease the formula starch gelatinization ratio, that decrease the air cells wall between the granules covered by gelatin lead to formula granules absorbed the water so easy.

\section{7-Evaluation of final breakfast cereal product quality}

The evaluation of the quality of the cereal breakfast produced by single screw extruder was carried out by comparing the product with 3 of different commercial cereal product unknowing the product condition $438 \mathrm{rpm}$ screw speed, $3 \mathrm{~mm}$ clearance between the last screw and extrusion die, 6 holes number of holes and 24\% formula moisture content , were so close from the commercial breakfast cereal as showed in Table(1).

Table :(1) The comparison between the commercial product and research product

\begin{tabular}{|c|c|c|c|c|}
\hline $\begin{array}{c}\text { Quality } \\
\text { Measurements }\end{array}$ & $\begin{array}{c}\text { Commercial } \\
\text { product } 1\end{array}$ & $\begin{array}{c}\text { Commercial } \\
\text { product } 2\end{array}$ & $\begin{array}{c}\text { Commercial } \\
\text { product } 3\end{array}$ & $\begin{array}{r}\text { Research } \\
\text { product }\end{array}$ \\
\hline Bulk density $\mathrm{g} / \mathrm{cm}^{3}$ & 0.532 & 0.674 & 0.435 & 0.716 \\
\hline Durability \% & 91.36 & 92.68 & 88.34 & 93.18 \\
\hline Product diameter \% & 7.79 & 7.13 & 9.67 & 6.9 \\
\hline Water absorption \% & 43.15 & 49.37 & 39.91 & 41.83 \\
\hline
\end{tabular}



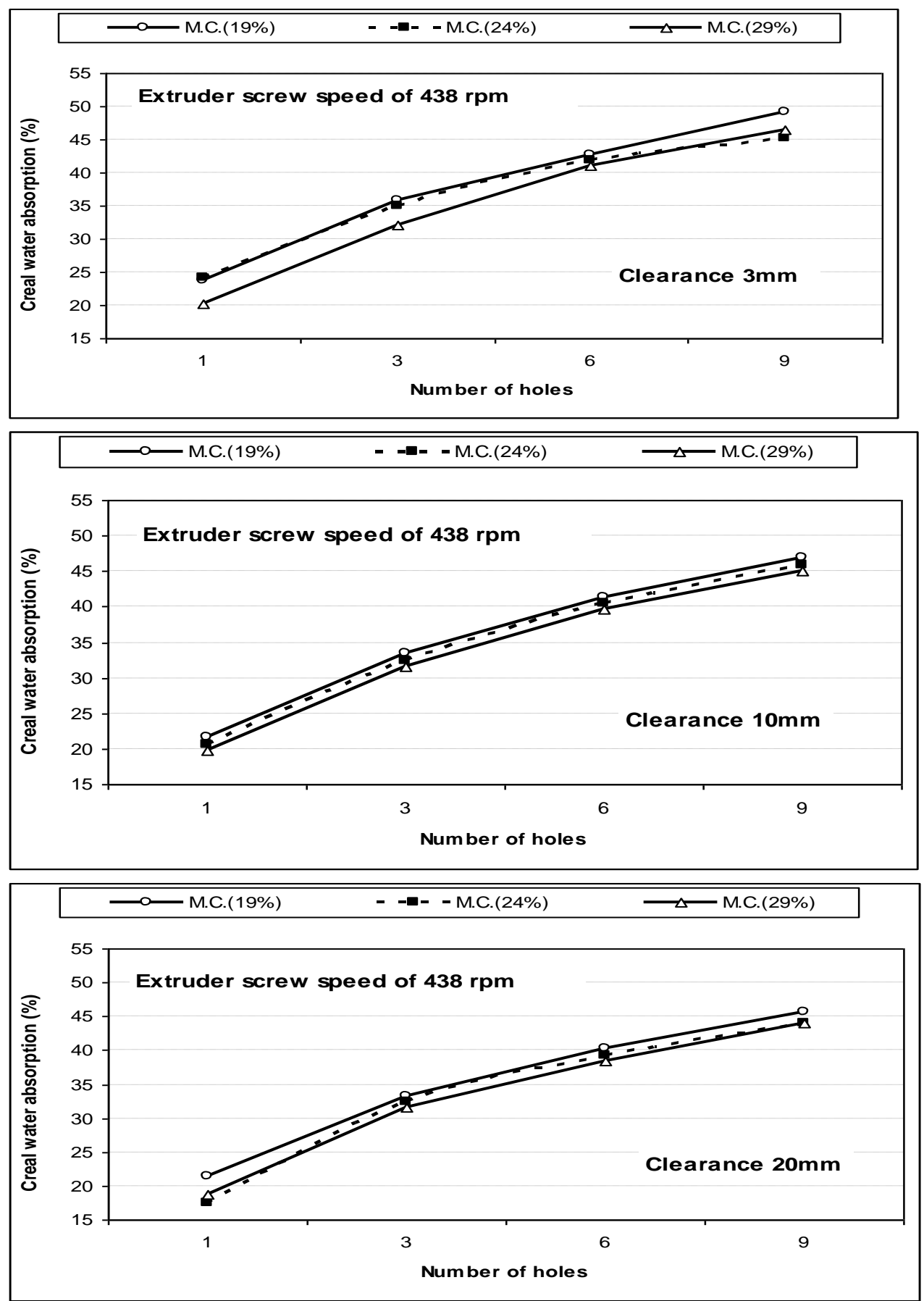

Fig. (11): Effect of physical and mechanical parameters on cereal water absorption. 
(type of extruder, formula moisture content, screw speed...etc) The obtained results of most effective operating range for the operating parameters were

\section{CONCLUSION}

The experimental results reveal that performance of the developed local single screw extruder used for producing expanded breakfast cereal was in the optimum region under the following conditions:

1- Screw speed of $438 \mathrm{rpm}$

2-Clearance between the last screw and extrusion die of $3 \mathrm{~mm}$

3-Holes number of 6 holes

4- Formula moisture content of $24 \%$

\section{REFERENCES}

AACC. 1984. Approved Methods of the AACC, 8th Ed., Method 44-15. American Association of Cereal Chemists. Paul, MN.

Alexander, R.J. 1979. Corn Dry Milling: Process, Products and Applications. In: Corn Chemistry and Technology, 351-375. S.A. Watson and P. E. Ramstad, eds. merican Association of Cereal Chemists. St Paul, MN.

Alvarez-Martinez, L., Kondury, K. P., and Harper, J. M. 1988. A general model for expansion of extruded products. J. Food Sci. 53:609-615.

ASAE 2000 S319.3: Method of determining and expressing fineness of feed materials by sieving. In ASAE Standards 2000, 563-566. St. Joseph, Mich.: ASAE.

Bhattacharya, M., and Hanna, M. 1987. Textural properties of extrusion-cooked corn starch. Lebensm.-Wiss. u.-Technol. 20:195201.

Colonna, P., Tayeb, J., and Mercier, C. 1989. Extrusion cooking of starch and starchy products. In Extrusion Cooking, 247-319. C. Mercier, P. Linko, and J. M. Harper, eds.American Association of Cereal Chemist, St Paulk, MN.

Desrumaux, A., Bouvier, J. M. and Burri, J. 1998. Corn grits particle size and distribution effects on the characteristics of expanded extrudates. J. Food Sci. 63:857-863. 
Ding Qing-Bo; Ainsworth, P.; Tucker, G. and H. Marson. 2005. The effect of extrusion conditions on the physicochemical properties and sensory characteristics of rice-based expanded snacks, Journal of ood Engineering, 66(3):283-289

Hoseney, R. C. 1994. Principles of Cereals, 2nd ed. American Association of Cereal Chemists, Inc. St Paul, MN.

Hsieh, F., Peng, I. C. and Huff, H. E. 1990. Effects of salt, sugar and screw speed on processing and product variables of corn meal extruded with a twin-screw extruder. J.Food Sci. 55:224-227.

Ibrahim, M. K. E., 1982, Wet milling wheat grain. M. Sc. Th., Fac. Of Agric. Mansoura Univ. $64-65$.

Jones,D., Chinnaswamy,R., Tan,Y., and Hanna.M. 2000. Physiochemcial properties of ready-to-eat breakfast cereals.CFW Research, American association of cereal chemists, Inc. 45(4)164168.

Nehru. C., K.Muthukumarappan, K.A. Rosentrater and J.L. Julson. 2006. Effect of die dimensions on extruder processing parameters and extrudate properties for distillers grains based feeds. 2006 ASABE Annual International Meeting Sponsored by ASABE. Portland Convention Center. Portland, Oregon. 9 - 12 July 2006.

Patil .R. T. , J. J. Berrios, J. Tang, J. Pan and B. Swanson .2005. Empirical Modeling of Extrusion Cooking of Chickpea Flour for Process Scale Up. 2005 ASAE Annual International Meeting Sponsored by ASAE. Tampa Convention Center .Tampa, Florida

17 - 20 July 2005

Patil, R.T.; Joshi, K.C.; Gupta, S. and A. Saran. 2000 Extrusion cooking characteristics of soywheat blends to produce ready to eat snacks.Journal of Agricultural Engineering(ISAE) 37(3): P11-19.

Rooney, L. W., and Serna-Saldivar, S.O. 1987. Food uses of whole corn and dry- milled fractions. In: Corn Chemistry and Technology, 399-429. S.A. Watson and P. E. Ramstad, eds. American Association of Cereal Chemists. St Paul, MN. 


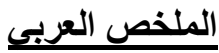

\section{تطوير آلة بثق محلية ذات بريمة مفردة لإنتاج المحبيات الغذائية}

* أسامة قدور

تستخدم آلات البثق بنو عيها في العديد من الصناعات الغذائية مثل( السناكس و المكرونة و الكورن

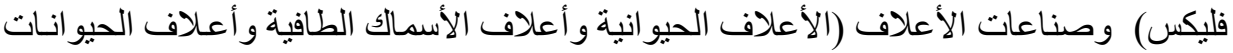

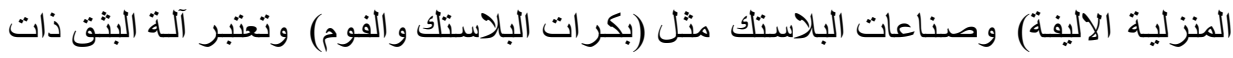

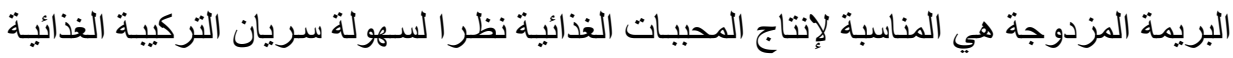

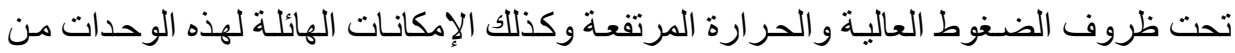
التحكم في درجات الحر ارة عند كل مقطع في وحدة البريمات

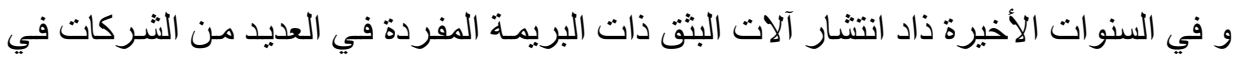

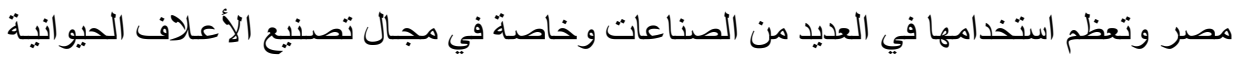

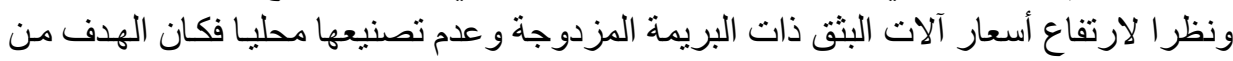

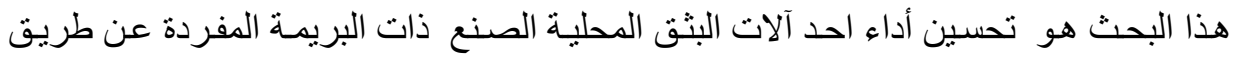

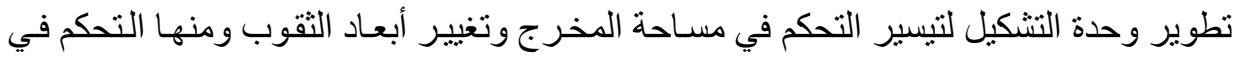

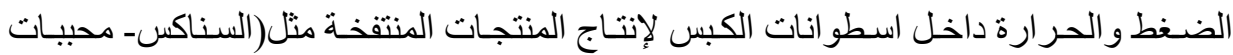

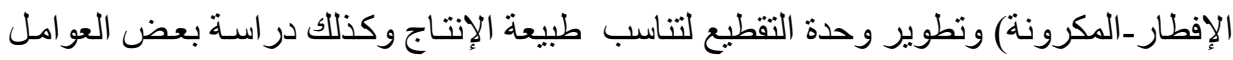

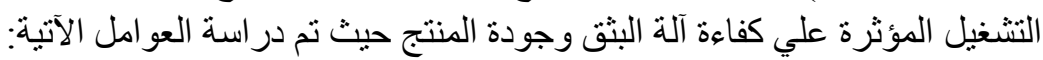

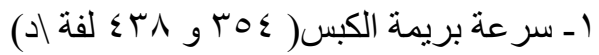

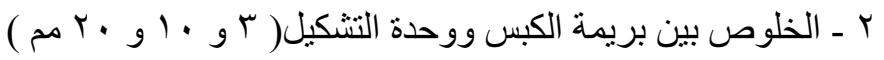

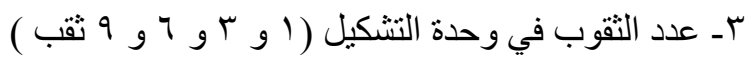

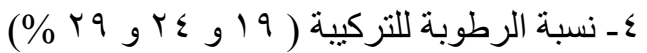

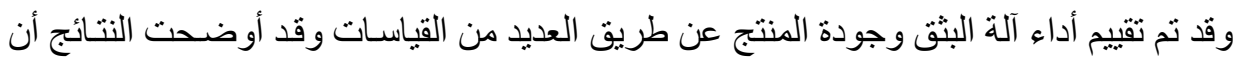

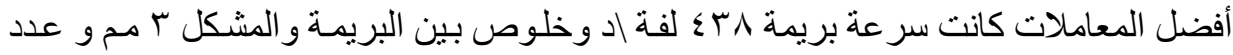

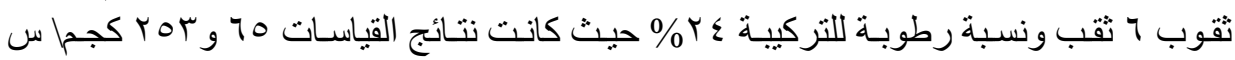

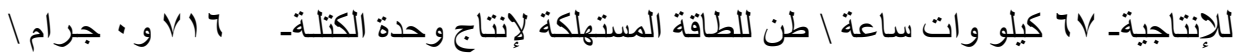

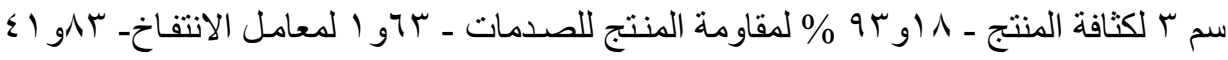
\% \% لنسبة امتصاص الماء

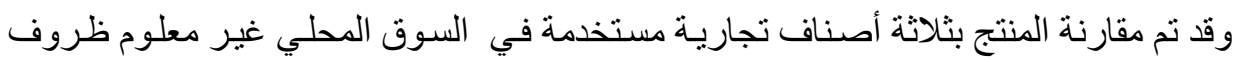

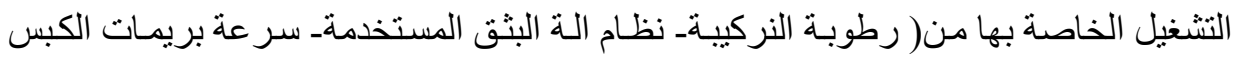
و الخ) وكانت نتائج قياسات الجودة قريبة نسبيا من نتائج هذه المنتجات التجارية.

* باحث أول ـ معهز بحوث الهندسة الزراعية ـ مركز البحوث الزراعية * 